University of Nebraska - Lincoln

DigitalCommons@University of Nebraska - Lincoln

USDA National Wildlife Research Center - Staff Publications
U.S. Department of Agriculture: Animal and Plant Health Inspection Service

May 2007

\title{
Subterranean Rodents as Pests: The Case of the Pocket Gopher
}

Gary W. Witmer

USDA-APHIS-Wildlife Services, gary.w.witmer@usda.gov

Richard M. Engeman

USDA-APHIS-Wildlife Services, s_r100@yahoo.com

Follow this and additional works at: https://digitalcommons.unl.edu/icwdm_usdanwrc

Part of the Environmental Sciences Commons

Witmer, Gary W. and Engeman, Richard M., "Subterranean Rodents as Pests: The Case of the Pocket Gopher" (2007). USDA National Wildlife Research Center - Staff Publications. 729.

https://digitalcommons.unl.edu/icwdm_usdanwrc/729

This Article is brought to you for free and open access by the U.S. Department of Agriculture: Animal and Plant Health Inspection Service at DigitalCommons@University of Nebraska - Lincoln. It has been accepted for inclusion in USDA National Wildlife Research Center - Staff Publications by an authorized administrator of DigitalCommons@University of Nebraska - Lincoln. 


\title{
21 Subterranean Rodents as Pests: The Case of the Pocket Gopher
}

\author{
Gary W. Witmer, Richard M. Engeman
}

\section{1 \\ Introduction}

With over 2000 species, the order Rodentia has more members than any other order of mammals (Nowak 1999). The distribution of rodents is nearly worldwide; their use of habitats is extensive and varied. Most rodent species are relatively small, secretive, prolific, and all have continuously growing incisors. Many rodent species have ecological, scientific, cultural, and/or economic importance.

A variety of economic and health problems result from rodent interactions with humans. These include damage to growing crops, trees, seeds, pastures; damage and contamination of stored foods; damage to structures and property; and disease transmission (Witmer et al. 1995a). Singleton et al. (2003) estimated that in Asia alone, the amount of grain eaten by rodents would provide enough food to feed 200 million Asians for a year.

Notably, few (perhaps 5\%) rodent species around the world are serious pests. Examples of genera and species of rodents considered to be serious pests around the world were provided by Prakash (1988) and Witmer et al. (1995a). Hence, when a damage situation occurs, it is very important to determine the species causing the damage, the extent of the damage, and the abiotic-biotic-cultural factors involved before rodent population and damage management strategies are implemented (Singleton et al. 1999).

We use the North American subterranean rodents, pocket gophers, to illustrate the nature of rodent pests, the types and extent of damages, and the management measures used to reduce populations and damage.

Gary W. Witmer: USDA/APHIS/WS National Wildlife Research Center, 4101 Laporte Avenue, Fort Collins, Colorado 80521-2154 USA, E-mail: Gary.W.Witmer@aphis.usda.gov

Richard M. Engeman: USDA/APHIS/WS National Wildlife Research Center, 4101 Laporte Avenue, Fort Collins, Colorado 80521-2154 USA 


\section{2}

\section{Pocket Gophers (Family Geomyidae)}

Pocket gophers are endemic to North America from central Canada to Panama. There are seven genera: Cratogeomys (sometimes considered a subgenus of Pappogeomys), Geomys, Heterogeomys, Orthogeomys, Pappogeomys, Thomomys, and Zygogeomys (Nowak 1999; Baker RJ et al. 2003). There are at least 35 species and about 300 subspecies within this family of rodents.

In general, pocket gophers have thick-set bodies with short necks and a head-body-length of $15-30 \mathrm{~cm}$. They are subterranean to a high degree, living in closed burrow systems. Pocket gophers have small eyes and pinnae, a good sense of touch, and stout forelegs with strong claws. They rarely venture to the surface except to push soil out, to occasionally clip and gather above ground vegetation, and for dispersal purposes. Except for mating and rearing young, most species live solitary lives within their burrow system.

Pocket gophers possess amazing digging and gnawing abilities, and have been extensively studied. Details of their biology, ecology, and environmental effects have been reviewed by Nevo (1999), Nowak (1999), Baker RJ et al. (2003), and Reichman (this volume).

\section{3}

\section{Damage by Pocket Gophers}

Pocket gophers commonly come into conflict with humans. This occurs through crop damage, rangeland damage, forest damage, and physical damage to structures and property (Marsh 1988). It may be a tribute to their ability to cause damage that Marsh (1988), in his chapter on rodent problems on the North American continent, discussed pocket gophers first amongst 21 rodent groups! He lists the damage by pocket gophers in North America as widespread and, on a site specific basis, as generally in the light-to-heavy damage categories. We review the types and extents of damage caused by pocket gophers. Unfortunately, much of the literature is dated and there is insufficient quantification of the damage.

\subsection{1}

\section{Forest Damage}

Pocket gophers are one of the most serious threats to reforestation in North America (Engeman and Witmer 2000). They kill young trees by debarking stems (sometimes called girdling) at the ground surface, pruning 
roots below ground, clipping seedlings aboveground, and pulling entire seedlings below ground. Damage higher up the boles of trees can occur with snow cover (pocket gophers are active year round). Damage to roots occurs mostly during the winter and early spring when herbaceous plants are less available. A wide array of tree species can be affected. Graham and Kingery (1990) reported that Thomomys gophers killed 71\% of the pine trees on plantations by year 6 after planting. Pocket gophers readily invade clearcut units, especially once herbaceous ground cover becomes abundant. When foresters replant the unit with seedlings, pocket gopher foraging can remove all or large portions of the seedlings. This requires replanting, often preceded by pocket gopher population control. This process greatly escalates total costs, often prompting foresters to routinely practice pocket gopher control prior to reforestation. Engeman and Witmer (2000) assessed the risk posed by Thomomys gophers and provided guidelines for how to avoid serious damage and when to apply pro-active measures. However, pocket gopher populations recover very quickly after control, by reproduction of survivors and by re-invasion from surrounding areas (Engeman and Campbell 1999). Hence, some researchers have recommended that forest management practices be modified to provide less suitable habitat for pocket gophers (Smallwood 1999; Engeman and Witmer 2000).

\subsection{2}

\section{Rangeland Damage}

The substantial impacts that Geomys gophers can have to rangelands was reviewed by Foster and Stubbendieck (1980). They documented 18-49\% reduction in range plant production on sites occupied by pocket gophers in Nebraska. This included an increase in some species of perennial grasses, but a decrease in coverage of annual forbs and annual grasses. Because of the soil mounding activities of pocket gophers, there was also an increase of $5-25 \%$ in bare soil coverage. They also cited studies reporting on range production changes: one reported an herbage reduction of $284 \mathrm{~kg} / \mathrm{ha}$ in California where Thomomys gophers occurred and another reported an herbage increase of $218 \mathrm{~kg} / \mathrm{ha}$ after Geomys gopher control in Colorado. Fitch and Bentley (1949) reported a 25\% forage reduction by Thomomys gophers in California. In Alberta, Canada, Alsager (1977) reported an 18\% decrease in forage production where Thomomys gophers were not controlled. He also noted a $16 \%$ increase in forage production within 60 days of pocket gopher control. 


\subsection{3 \\ Fruit Tree Damage}

Documentation of Thomomys gopher damage to fruit trees has included apple, cherry, and pear trees in the Pacific Northwest (Sullivan et al. 1987; Sullivan and Hogue 1987) and citrus trees in California (Cummings and Marsh 1978). In Guatemala, Orthogeomys gophers damage banana trees (Caid 1959) as do Orthogeomys and Pappogeomys gophers in Mexico (Whisson and Villa Cornejo 1996). Similar to forestry damage, this type of damage mostly involves root gnawing and basal girdling, with young trees ( $\leq 10$ years old) most susceptible. Sullivan et al. (1987) noted that the damage in apple orchards did not seem related to soil type, perhaps because the orchards were irrigated and fertilized, and about $30-40 \%$ of surveyed orchards had Thomomys gopher damage. Sullivan and Hogue (1987) reported that the incidence of rodent damage (voles and Thomomys gophers) dropped from $40.6 \%$ to $9.6 \%$ once the rodents were controlled. They also achieved better rodent control by greatly reducing low ground vegetation with herbicides rather than using rodenticides.

\subsection{4}

\section{Alfalfa and Field Crop Damage}

Pocket gophers cause substantial damage to alfalfa crops in southern Canada and throughout the midwestern plains and western states of the USA. Case (1989) reported reductions in yield of 17-49\% from Geomys gophers. They caused declines in yield in Nebraska of $30.2 \%$ in hay meadows and $16.7 \%$ in alfalfa fields (Hegarty 1984). The main declines were in some late successional perennial grasses and clovers. Losses were directly correlated with pocket gopher density and the percent of their mound cover. $\mathrm{He}$ also documented an increase in plant diversity because many annuals (including invasive and "weedy" plant species) germinated on the bare soil of the mounds. Similarly, Luce et al. (1981) documented alfalfa yield reductions of $40 \%$ in Nebraska. Jasch et al. (1992) estimated the economic losses in alfalfa production in Nebraska to be about $\$ 10$ million per year. They noted that fibrous-rooted varieties of alfalfa seem to better withstand pocket gopher damage. Proulx (2002) estimated losses to alfalfa fields in Alberta and Manitoba, Canada, by Thomomys gophers at \$15-30 million per year. He also compared the costs of various methods of pocket gopher control and noted an 18-28\% increase in yield after control. Case and Timm (1984) created a computer model to calculate the dollar loss due to Geomys gopher activity so returns on control costs could be weighed 
against yield increases. In a survey of alfalfa producers in Nevada, Lewis and O'Brien (1990) identified Thomomys gophers as the main pest rodent, present on $87 \%$ of the farms. The main problems associated with the pocket gophers were, in declining order, 1) loss of yield, 2) equipment damage, 3 ) an increase in labor and fuel costs, and 4) a decrease in hay quality. Pocket gopher control was practiced by $80 \%$ of the farmers, but $53 \%$ (the largest proportion of farmers) said it was only "somewhat effective". Next to irrigation costs, they reported vertebrate pest management costs as their greatest expense; even higher than weed and insect management costs and fertilizer costs. Smallwood and Geng (1997) noted the relationship between damage level and Thomomys gopher density, but also explained that complex relationships exist: for example, the field may produce a higher yield a year after some gopher damage than it had averaged before gopher infestation, and more productive lands can sustain more damage.

Pocket gophers also damage other field crops. Villa Cornejo (2000) reported over 200,000 ha of sugarcane fields in Mexico had evidence of Orthogeomys gopher damage. She examined over 66,000 individual stalks and found about $21 \%$ had been damaged by pocket gophers. Whisson and Villa Cornejo (1996) examined over 1400 corn stalks in Mexico and found about 4\% had Orthogeomys and/or Pappogeomys gopher damage. They mentioned other crops damaged, including wheat, potatoes, and cocoa, but gave no specifics.

\subsection{5}

\section{Wire and Cable Damage}

Connolly and Landstrom (1969) provided a good review of pocket gopher damage to buried cables. They considered the various species of Geomyidae to be the most significant source of animal damage to buried electrical and communication cables, noting smaller cable diameters sustained greater damage. Gophers were surmised to encounter and damage cables while seeking their main food source, roots. Most damage seems to occur in the rooting zone, $10-30 \mathrm{~cm}$ deep. They and other researchers (e.g. Hegdal and Harbour 1991; Ramey and McCann 1997) tested many types of cable coating, but in general, only a hard metal sheath or placement in a large-diameter $(\geq 5.5 \mathrm{~cm})$ conduit provided adequate protection from Geomys gophers. Isaac (1959) suggested that compacting soils in cable trenches would reduce Geomys gopher damage. He also recommended avoiding cable placement in areas of substantial pocket gopher activity. Cables are less likely to be damaged by gophers if they are placed more deeply underground because gopher burrows rarely exceed 
$2 \mathrm{~m}$ in depth (Case and Jasch 1994). Small diameter underground irrigation pipes also sustain pocket gopher damage (Hegdal and Harbour 1991).

\subsection{6 \\ Hydraulic Structure Damage, Disturbance of Hazardous Waste and Archaeological Sites}

Pocket gophers are truly efficient "digging machines". Smallwood and Morrison (1999) reviewed studies reporting the excavation rate and burrow volumes of various species of pocket gophers. They found much variation which they attributed to the varying species, study locations, and methodologies used. In general, however, a single Geomys or Thomomys gopher can excavate $18 \mathrm{~m}^{3}$ per ha per year and its burrow has a volume of at least $0.68 \mathrm{~m}^{3}$. Hence, it is not surprising that earthen structures (dikes, canals, and levees) can sustain substantial damage from pocket gophers (Hegdal and Harbour 1991). This results in seepage, piping, and eventually, washouts (especially with water surges).

Several researchers have noted that Thomomys gophers can disrupt the integrity of waste burial sites and this is especially of concern when hazardous wastes are involved (Winsor and Whicker 1980; Hakonson et al. 1982; Sejkora 1989; Bowerman and Redente 1998; Smallwood et al. 1998). Hakonson et al. (1982) did not believe that much material was being brought to the surface, but a considerable "void space" was being created in the soil cover profile. Winsor and Whicker (1980) found that pocket gophers were bringing buried plutonium to the surface at a waste site in Colorado. The highest radioactivity counts were in the $0-10 \mathrm{~cm}$ soil layer and in the pocket gopher mounds. They noted that most burrowing activity was in the top $30 \mathrm{~cm}$ of the soil. On the other hand, Sejkora (1989) noted that pocket gopher burrowing activities reduced runoff, soil erosion, and chemical transport of surface materials.

Pocket gopher burrowing can disturb archaeological materials and burial sites. Bocek (1992) reported that Thomomys gophers often redistributed items in disproportionate ways; smaller items were moved nearer to the surface while larger items settled to greater depths. 


\subsection{7 \\ Invasive Plant Establishment and Dispersal}

The disturbance of soil and seed dispersal by rodents has been suggested to enhance the establishment of invasive plant species (e.g., Case and Jasch 1994; Hobbs and Mooney 1991). The large increase in bare soil on the surface resulting from pocket gopher burrowing provides abundant germination sites for annual plants. The magnitude of this effect on the establishment and spread of invasive plants has not been well documented and the relationships between abiotic and biotic factors can be quite complex (see Reichman, this volume).

\section{4}

\section{Pocket Gopher Damage Management}

Because of the extensive nature of pocket gopher damage, many tools, methods, and strategies have been developed to reduce populations and damage (Case and Jasch 1994; Engeman and Witmer 2000; Marsh 1992). With rodents, the amount of damage is often related to the population density; hence, one approach to damage reduction is to reduce the pocket gopher population in the area of the damage. A second approach is to reduce the area's carrying capacity for pocket gophers, or to provide protection to specific resources so that they are less likely to be damaged by pocket gophers living in the area. Often a combination of methods is the best way to achieve significant rodent damage reduction. This concept of Integrated Pest Management (IPM) has been elaborately developed for many pest groups (insects, weeds, disease organisms and their vectors), but less so for vertebrate pests. In dealing with rodent pests, Singleton et al. (1999) took this concept a step further and proposed an "ecologically-based rodent pest management" system that goes well beyond the traditional, heavy reliance on toxic rodenticides. We briefly review the various methods employed to reduce damage by pocket gophers.

\subsection{1}

\section{Pocket Gopher Population Control}

Humans around the world have relied on kill traps and rodenticide baits as the main tools to reduce damage by rodents, although many other methods have been used with varying levels of success (Witmer et al. 1995a). The use and effectiveness of traps for pocket gopher control has been reviewed by Marsh (1998), Pipas et al. (2000), Proulx (1997), and Witmer et al. (1999). 
One of the main problems with traps is they are very labor intensive to use. Because pocket gophers traps are placed down in the burrow, non-target animal losses are generally relatively low.

Rodenticides currently registered in the USA for use in pocket gopher control include chlorophacinone, diphacinone, strychnine, and zinc phosphide (Case and Jasch 1994). Burrow fumigants (gas cartridges, aluminum phosphide pellets) are also registered for gopher control (Baker RO 2004; Case and Jasch 1994). Marsh (1992) discussed the history of rodenticide use for gopher control in California, including several rodenticides no longer registered for that purpose. Other rodenticides, such as cholecalciferol, have proven effective in gopher control and may be registered for that use in the future (Witmer et al. 1995b). Most rodenticides can be classified as anticoagulants, which are further broken down into first and second generation materials, and the acute toxicants (see Timm 1994). The first generation anticoagulants (e.g., warfarin, chlorophacinone, diphacinone) are relatively lower in toxicity and require multiple feedings over several days before they are lethal to the rodent. The second generation anticoagulants (e.g., bromaliolone, brodifacoum) are more potent and were developed starting in the early 1970s when genetic resistance to first generation anticoagulants began to occur. Anticoagulants are used in relatively low concentrations $(0.0025-0.005 \%)$ and an antidote (vitamin $\mathrm{K})$ exists in case of accidental intoxication of people, pets or livestock. The acute toxicants (e.g., zinc phosphide, strychnine, cholecalciferol, bromethalin) are toxic to most vertebrates and may kill rodents with a single feeding. Rodenticides are carefully regulated by federal, provincial, territorial, and state agencies to assure proper use and to reduce adverse effects. Concerns with rodenticide use revolve around primary and secondary poisoning hazards, residue bioaccumulation, and environmental persistence. Because pocket gopher rodenticide baits are placed within the burrow which is then sealed over, the hazards to non-target animals are relatively low. In general, the use of rodenticide baits $(\$ 30 / \mathrm{ha})$ is more cost effective than the use of traps ( $\$ 100 /$ ha; Proulx 2002). Use of a tractor-drawn burrow builder that systematically dispenses bait into the burrow as it is created can keep costs even lower (\$6/ha; Proulx 2002).

Pocket gopher populations can be quickly reduced with traps or rodenticides, but they typically recover within a year to pre-control levels (Engeman and Campbell 1999; Engeman and Witmer 2000). For this reason, Proulx (2002) recommended the implementation of a "border control" strategy. After an area is cleared of pocket gophers, some trappings (or bait applications) are continued around the perimeter to reduce the re-invasion rate. 


\subsection{2 \\ Habitat Management and Resource Protection}

Some land management activities can help reduce pocket gopher densities and damage. These include the use of less palatable species or varieties of plants, crop rotation, alteration of planting and harvesting dates, flood irrigation, less canopy removal with forest harvest, less ground surface disturbance (to discourage herbaceous plant invasion of the site), use of herbicides or livestock to reduce ground forage, and encouragement of natural predation (Case and Jasch 1994; Engeman and Witmer 2000). For some situations, increasing the seedling stocking rate may be an effective and less costly alternative to other more expensive or legally restricted damage control methods (Engeman et al. 1998). Pocket gophers generally prefer to feed on forbs (dicots) over grasses (monocots) (Keith et al. 1959). Consequently, the selective removal of forbs with the herbicide 2,4-D has reduced Thomomys gopher densities (Keith et al. 1959; Tietjen et al. 1967).

Individual trees can also be protected with barriers made of small mesh wire or plastic tubes (Engeman et al. 1999a; Engeman and Witmer 2000). Unfortunately, this is costly because of initial material cost, the cost of maintenance, and overall labor cost. Care must also be taken to assure that the barriers do not affect the growth form of the trees and do not create a lethal thermal microclimate around seedlings.

There has been considerable research on pocket gopher repellents to protect trees, but these have not proven effective (Engeman and Witmer 2000). Some researchers feel predator odors (urine or feces) help keep rodents out of areas, but this has not been well documented (Witmer et al. 1997). Sonic or vibrator devices have not proven effective at driving underground rodents from an area (Timm 2003).

\subsection{3}

\section{Population Densities and Monitoring}

Densities of pocket gophers are highly variable. For Thomomys, densities are commonly $40-50$ per ha, but can be as high as 153 per ha (Case and Jasch 1994). For Geomys, densities are usually no greater than 20 per ha (Case and Jasch 1994). Densities are considered to be influenced by such factors as local climate, soil suitability, body mass, and vegetation types (Baker RJ et al. 2003). Sharp declines in gopher populations have occasionally been noted. These are usually related to a climatic factor such as a rapid snowmelt with a subsequent rise in the ground water level (Case and Jasch 1994). Pocket gopher populations, however, do not exhibit regular cycles in densities like those observed with some microtine species. 
Monitoring the level and distribution of activity for pocket gopher populations is essential to the decision-making process on whether and where to apply control technologies. Subterranean animals must be observed indirectly, using signs to reflect abundance, distribution, and level of activity. Forest pocket gopher activity usually is assessed by examining sample plots for new mounds (Anthony and Barnes 1984) or monitoring opened burrows for closure (Richens 1967). Mound building activity fluctuates seasonally, whereas pocket gophers always try to maintain closed burrow systems. Thomomys gopher burrow systems have a single occupant during much of the year. Thus, open-hole assessments are most valuable when assessing the effectiveness of direct population control measures (Engeman et al. 1993). Generally, two or three holes are opened in each burrow system and rechecked for closure after 24-48 h. Hole closure indicates an occupied burrow system. Parameters for applying the open-hole method have been optimized to maximize sensitivity of the results relative to in-field labor (number of holes opened and size of activity plots; Engeman et al. 1999b). The open-hole method is more difficult to interpret for species having more than one burrow occupant (Matschke et al. 1994).

\section{5}

\section{Conclusions and Future Needs}

Pocket gophers are subterranean rodents widely distributed across Canada, the United States, and south to Panama. Pocket gophers cause substantial damage to a wide array of resources through their foraging, burrowing, and gnawing habits. Population control measures are frequently implemented to reduce their numbers and subsequent damage. Control requires a diligent, long-term commitment with substantial funds, because pocket gophers can achieve high densities and rapidly reinvade sites having good resources. Thus, control should not be undertaken unless significant damage levels are anticipated.

More research is needed to understand better the nature of pocket gopher damage to crops and other resources, and ways in which to reduce that damage. Evaluations of existing methods are still needed in many places. The ability to develop new, safe, and effective methods of rodent damage management will depend on many factors, besides laboratory, pen, and field trials: funding, actions by regulatory agencies, interest and involvement by commercial developers of methods and products, and pressures by agricultural producers, special interest groups, and the general public. 


\section{References}

Alsager DE (1977) Impact of pocket gophers on the quantitative productivity of rangeland vegetation in southern Alberta: a damage assessment tool. In: Jackson W (ed) Test methods for vertebrate pest control and management materials, ASTM STP 625, Am Soc Test Mat, Philadelphia, pp 47-57

Anthony RM, Barnes VG Jr (1984) Plot occupancy for indicating pocket gopher abundance and conifer damage. In: Kaukeinen DE (ed) Vertebrate Pest Control and Management Materials: Fourth Symposium, ASTM STP 817, Am Soc Test Mat, Philadelphia, pp 247255

Baker RJ, Bradley RD, McAliley LR (2003) Pocket gophers. In: Feldhamer GA, Thompson BC, Chapman JA (eds) Wild mammals of North America. Johns Hopkins Univ Press, Baltimore, pp 276-287

Baker RO (2004) Field efficacy of Fumitoxin (55\% aluminum phosphide) tablets for controlling valley pocket gophers. Proc Vertebr Pest Conf 21:253-257

Bocek B (1992) The Jasper Ridge reexcavation experiment: rates of artifact mixing by rodents. Am Antiq 57:261-269

Bowerman AG, Redente EF (1998) Biointrusion of protective barriers at hazardous waste sites. J Environ Qual 27:625-632

Caid RD (1959) Taltuza investigations in Guatemala. Res Newsl (Department of Fruit, United Fruit Company, Boston) 6:15-20

Case RM (1989) Managing damage to alfalfa caused by plains pocket gophers. Proc Great Plains Wildlife Damage Control Workshop 9:160-161

Case RM, Jasch BA (1994) Pocket gophers. In: Hygnstrom SE, Timm RM, Larson GE (eds) Prevention and control of wildlife damage. Nebraska Cooperative Extension, Lincoln, pp B-17-B-29

Case RM, Timm RM (1984) Economic model of pocket gopher control. Proc Great Plains Wildlife Damage Control Workshop 6:53-56

Connolly RA, Landstrom RE (1969) Gopher damage to buried cable materials. Mater Res Stand 9:13-16

Cummings MW, Marsh RE (1978) Vertebrate pests of citrus. The citrus industry, vol IV, Publication 4088, Univ California, Div Agr Sci, Davis, pp 237-273

Engeman RM, Campbell DL (1999) Pocket gopher reoccupation of burrow systems following population reduction. Crop Prot 18:523-525

Engeman RM, Witmer GW (2000) Integrated management tactics for predicting and alleviating pocket gopher damage to conifer reforestation plantings. Integr Pest Manag Rev 5:41-55

Engeman RM, Campbell DL, Evans J (1993) A comparison of 2 activity measures for northern pocket gophers. Wildl Soc Bull 21:70-73

Engeman RM, Anthony RM, Barnes V, Krupa HW, Evans J (1998) Double-stocking for overcoming damage to conifer seedlings by pocket gophers. Crop Prot 17:687-689

Engeman RM, Anthony RM, Barnes V, Krupa HW, Evans J (1999a) Evaluations of plastic mesh tubes for protecting conifer seedlings from pocket gophers in three western states. Western J Appl For 14:86-90

Engeman RM, Nolte DL, Bulkin SP (1999b) Optimization of the open-hole method for assessing pocket gopher activity. Can Field Nat 113:241-244

Fitch HS, Bentley JR (1949) Use of California annual-plant forage by range rodents. Ecology 30:306-321

Foster MA, Stubbendieck J (1980) Effects of the plains pocket gopher on rangeland. J Range Manag 33:74-78 
Graham RT, Kingery JL (1990) Seedling damage and mortality of conifer plantations on transitory ranges in northern and central Idaho. Proc Vertebr Pest Conf 14:209-213

Hakonson TE, Marinez JL, White GC (1982) Disturbance of low-level waste burial site cover by pocket gophers. Health Phys 42:868-871

Hegarty PJ (1984) Effects of the plains pocket gopher on hay meadows and irrigated alfalfa in the Nebraska sandhills. MSc Thesis, Univ Nebraska, Lincoln

Hegdal PL, Harbour AJ (1991) Prevention and control of animal damage to hydraulic structures. US Department of Interior, Bureau of Reclamation, Washington, D.C.

Hobbs RJ, Mooney HA (1991) Effects of rainfall variability and gopher disturbance of serpentine annual grassland dynamics. Ecology 72:59-68

Isaac RL (1959) Pocket gopher damage to underground telephone wire in Caddo County, Oklahoma. USDA Division of Wildlife Services, Oklahoma City

Jasch B, Case RM, Luchsinger JC (1992) Pocket gopher damage and alfalfa root structure. Proc Nebraska Acad Sci 102:28

Keith JO, Hansen RM, Ward AL (1959) Effect of 2,4-D on abundance and foods of pocket gohers. J Wildl Manag 23:137-145

Lewis SR, O’Brien JM (1990) Survey of rodent and rabbit damage to alfalfa hay in Nevada. Proc Vertebr Pest Conf 14:116-119

Luce DG, Case RM, Stubbendieck JL (1981) Damage to alfalfa fields by plains pocket gopher. J Wildl Manag 45:258-260

Marsh RE (1988) Rodent problems on the North American continent. In: Prakash I (ed) Rodent pest management. CRC Press, Boca Raton, pp 1-11

Marsh RE (1992) Reflections on current (1992) pocket gopher control in California. Proc Vertebr Pest Conf 15:289-292

Marsh RE (1998) One hundred years of pocket gopher traps and trapping. Proc Vertebr Pest Conf 18:221-226

Matschke GH, Sterner RT, Engeman RM, O’Brien JM (1994) Limitations of open-hole and plot occupancy indices in field efficacy studies with Townsend's pocket gophers. Proc 15th Annual SETAC meeting, Denver, 15:245

Nevo E (1999) Mosaic evolution of subterranean mammals: regression, progression and global convergence. Oxford Univ Press, Oxford

Nowak RM (1999) Mammals of the world. Johns Hopkins Univ Press, Baltimore

Pipas MJ, Matschke GH, McCann GR (2000) Evaluation of the efficacy of three types of traps for capturing pocket gophers. Proc Vertebr Pest Conf 19:385-388

Prakash I (1988) Rodent pest management. CRC Press, Inc., Boca Raton

Proulx G (1997) A preliminary evaluation of four types of traps to capture northern pocket gophers. Can Field Nat 111:640-643

Proulx G (2002) Effectiveness of trapping to control northern pocket gophers in agricultural lands in Canada. Proc Vertebr Pest Conf 20:26-31

Ramey A, McCann GR (1997) Evaluating cable resistance to pocket gopher damage - a review. Proc Great Plains Wildlife Damage Control Conf 13:107-113

Richens VB (1967) The status and use of gophacide. Proc Vertebr Pest Conf 3:118125

Sejkora KJ (1989) Influence of pocket gophers on water erosion and surface hydrology. Dissertation. Colorado State Univ, Fort Collins

Singleton GR, Leirs H, Hinds LA, Zhang Z (1999) Ecologically-based management of rodent pests - re-evaluating our approach to an old problem. In: Singleton G (ed) Ecologicallybased management of rodent pests. Austr Centre Intl Agricult Res, Canberra, pp 17-29

Singleton GR, Hind LA, Krebs CJ, Spratt DM (2003) Rats, mice, and people: rodent biology and management. Austr Centre Intl Agricult Res, Canberra 
Smallwood KS (1999) Abating pocket gophers to regenerate forest clearcuts. Environ Conserv 26:59-65

Smallwood S, Geng S (1997) Multiscale influence of gophers on alfalfa yield and quality. Field Crops Res 49:159-168

Smallwood KS, Morrison ML (1999) Estimating burrow volume and excavation rate of pocket gophers. Southwest Nat 44:173-183

Smallwood KS, Morrison ML, Beyea J (1998) Animal burrowing attributes affecting hazardous waste management. Environ Manag 22:831-847

Sullivan TP, Hogue EJ (1987) Influence of orchard floor management on vole and pocket gopher populations and damage in apple orchards. J Am Soc Hort Sci 112:972-977

Sullivan TP, Krebs JA, Kluge HA (1987) Survey of mammal damage to tree fruit orchards in the Okanogan Valley of British Columbia. Northwest Sci 61:23-31

Tietjen HP, Halvorson CH, Hegdal PL, Johnson AM (1967) 2,4-D herbicide, vegetation, and pocket gopher relationships, Black Mesa, Colorado. Ecology 48:634-643

Timm RM (1994) Active ingredients. In: Hyngstrom S, Timm RM, Larson GE (eds) Prevention and control of wildlife damage. Nebraska Cooperative Extension Service, Lincoln, pp G-23-G-61

Timm RM (2003) Devices for vertebrate pest control: are they of value? Proc Wildl Damage Manage Conf 10:152-161

Villa Cornejo B (2000) Pocket gopher damage in sugarcane fields in the state of Veracruz, Mexico. Proc Vertebr Pest Conf 19:358-361

Whisson D, Villa Cornejo B (1996) The pocket gopher as a pest in Mexico. Proc Vertebr Pest Conf 17:151-153

Winsor TF, Whicker FW (1980) Pocket gophers and redistribution of plutonium in soil. Health Phys 39:257-262

Witmer GW, Fall MW, Fiedler LA (1995a) Rodent control, research needs, and technology transfer. In: Bissonette J (ed) Integrating people and wildlife for a sustainable future. The Wildlife Society, Bethesda, pp 693-697

Witmer GW, Matschke GH, Campbell DL (1995b) Field trials of pocket gopher control with cholecalciferol. Crop Prot 14:307-309

Witmer GW, Sayler RD, Pipas MJ (1997) Repellent trials to reduce reforestation damage by pocket gophers, deer, and elk. In: Mason JR (ed) Repellents in wildlife management, USDA National Wildlife Research Center, Fort Collins, pp 321-332

Witmer GW, Marsh RE, Matschke GH (1999) Trapping considerations for the fossorial pocket gopher. In: Proulx G (ed) Mammal trapping. Alpha Wildlife Research and Management, Ltd., Sherwood Park, pp 131-139 